\title{
Table of Contents / Содержание
}

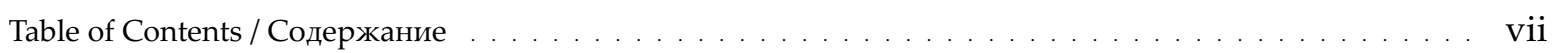

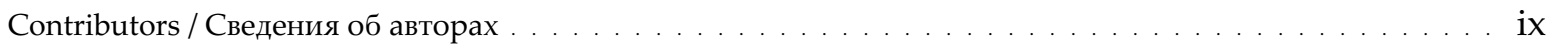

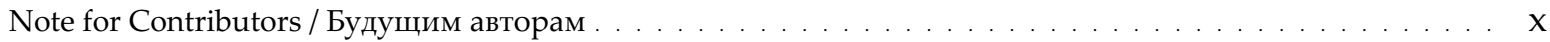

\section{Issue 3 / Часть 3}

\section{Articles / Статьи}

Eugene Helimski. S-singulatives in Ket

[Е. А. Хелимский. Сингулятивы на -s в кетском языке]

Andrey V. Nikulin. Historical phonology of Proto-Northern Jê

[А. В. Никулин. Историческая фонетика северной ветви семьи же]

\section{Discussion Articles / Дискуссионные статыи}

H. Craig Melchert. Initial *sp- in Hittite and šip(p)and- 'to libate'

[Крейг Мелчерт. Начальный кластер *sp- в хеттском языке и глагол šip(p)and- 'жертвовать']

Ilya S. Yakubovich. Response to C. Melchert

[И. С. Якубович. Ответ К. Мелчерту]

\section{Reports / Хроника}

Towards Proto-Niger-Congo: Comparison and Reconstruction, Paris, LLACAN,

September 1-3, 2016 (Galina Sim)

\section{Book Reviews / Рецензии}

С. В. КулААНДА. Скифы: язык и этногенез [Sergei KULLANDA. The Scyths: language and ethnogenesis], 2016 (П. В. Башарин)

Carlotta VITI (ed.). Perspectives on historical syntax, 2015 (Maria A. Molina)

\section{Issue 4 / Часть 4}

\section{Articles / Статьи}

Anton I. Kogan. Genealogical classification of New Indo-Aryan languages and lexicostatistics 
М. Е. Васильев, М. Н. Саенко. К вопросу о точности глоттохронологии: датирование процесса лексических замен по данным романских языков

[Mikhail E. Vasilyev, Mikhail N. Saenko. How accurate glottochronology can be?

Dating the lexical replacement process in the Romance languages]

И. С. Якубович. Славянский чертежник: этимология слав. *čъrtъ 'черт' [Ilya S. Yakubovich. The Slavic draughtsman: etymology of Slav. *čbrtb 'devil']

Mikhail A. Zhivlov. The origin of Khanty retroflex nasal

[M. А. Живлов. Происхождение хантыйского ретрофлексного носового] 